\title{
TEXT \& CONTEXT NURSING JOURNAL AND ITS CONTRIBUTION FOR THE SCIENTIFIC PRODUCTION OF NURSING: 25 YEARS OF HISTORY (1992-2017)
}

On March 24 ${ }^{\text {th }}$ 1992, Dr. Ingrid Elsen, Coordinator of the Post-Graduate Nursing Program (PGNP) at the Federal University of Santa Catarina (FUSC), met a group of professors todiscuss the creation of a journal, with the initial purpose of socializing and disseminating the produced knowledge in the 16 years of the program's existence, as well as the recently created Doctoral Program in Philosophy of Nursing.

It was decided by the title "Text \& Context", thinking about the future and of its mission related to disseminate the technical-scientific production of Nursing and Health to the national and international scientific community, as well to professionals and managers of the health area.

From the beginning, the journal was highlighted as innovative, marked by the decision of the first management group, to make this the first thematic journal in Nursing. Based on relevant issues and themes experienced by the Brazilian nursing, but also attentive to the international scenario and aiming to attend to the philosophy of PGNP/FUSC, each issue of the Journal went on to address a specific topic, discussed under various perspectives and different angles.

This option brought another benefit to the scientific community, which was to have at its disposal a journal with all the most current material on a given topic1. In the following years, many were the topics addressed by the Journal, which covered a wide range of theoretical, conceptual and methodological discussions in the area of health and nursing. ${ }^{2-3}$

The journal begins with a semiannual publication period until 1996, after four-monthly (1997-2002) and, since 2003, it has been consolidated as a quarterly journal. Until 2002, the layout and layer followed the pattern of different colors for each volume and was printed in size A5, with about 15 to maximum 20 articles in each number, being just printed and sale by subscription.

After completing ten years of existence, the Director of the Journal at the time radically changed the layout and layer, making it a journal in a single color, similar to purple, which was the color adopted by the PEN / UFSC.

In addition to that, the size became A4, which offered the opportunity to expand the number of articles in each of the numbers, being at least 20, the required and expected. The changes also sought to respond to the recommendations of the development agencies, as well as the needs in terms of standardization, periodicity, editorial body, and consequently, to reach indexing bodies considered the most qualified worldwide.

Taking into account the publishing market and the possibility of immediate dissemination of the produced knowledge, we offered to the national and international academic community, in addition to the printed version, the on-line version since 2006, the open acess in full text and in its own virtual environment (http://www.textoecontexto.ufsc.br). In the same year, it became part of the Virtual Health Library (VHL) - Nursing Portal and, from 2007, became part of the SciELO Brazil collection, available in integral text and open access. ${ }^{3}$

These inclusions favored the access to the published articles in the journal, as well as, the extension of the citation of the same in other journals. In order to attend a wider range of international readers/ authors, they also accepted publications in English and Spanish.

It is characterized and consolidated from there, as a journal of international circulation and has its recognized importance, especially in its impact for dissemination of the products and evaluation of the Post-Graduated Programs in Nursing in Brazil. 
After 18 years of existence as a thematic journal, the Journal's Board of Directors decided to make Texto $\mathcal{E}$ Contexto Enfermagem a multi-thematic journal. This decision took into consideration, especially the immense search for articles of the journal, the need to expand the number of articles by published number, as well as, to make more agile the publication of each number. ${ }^{2-3}$

This change sought to accompany the rapid growth of shipping requests in recent years and to expand the possibilities of socializing scientific information, derived from the various areas of health and nursing. ${ }^{3}$ It continued to publish special numbers, maintaining the previous policy of at least a special number per year, derived from scientific events in the area of nursing.

Among the advances made to maintain the quality of the Texto \& Contexto Enfermagem and the adherence to the editorial policy of the same, was modified in 2010, the management group of the Journal. The journal went on to have associated editors, to extend the qualitative support in the work of Editor, that is, the functions of the Posting Editor, Manuscript Selection Editor and Text and Layout Editor.

Complementing this decision, the pre-analysis of the submitted manuscripts was also introduced, which benefits both, the authors who have an earlier decision on the acceptance or not, of their manuscripts, for the continuity of the evaluative process, as well as for the Editorial team of the journal, in the selection of Ad Hoc consultants. ${ }^{1}$

The policy of having international External Associate Editors was adopted, from Latin America, Europe and North America. Other decisions taken in 2011 in order to accompany the trends of the journals with the greatest impact, were the following: the revision of the ad hoc panel of consultants annually, the publication in English of all articles since the first issue of 2012, the availability of the Jurnal only in the online version since 2012, the cancellation of subscriptions since 2012, keeping only the payment of shipping fees and publication, expansion and updating of the National and International Editorial Board, the publication of at least 120 articles per year, the exclusive submission through the SciELO SchoolarOne Manuscripts Database, starting in 2014, the publication of articles ahead of print. In 2015, we implemented the Ithenticate plagiarism detector (ABEC Agreement with the Cross Reference).

In 2016, the revision of the rules of sending and publishing and of the editorial processes was carried out. The mode ahead of print was replaced by the Rolling Pass mode. In addition, an agreement was signed with the SciELO database to link the Rev@Enf, a project that integrates the Virtual Library in Health - Nursing, collaboration between the Institutions responsible for the publications of the Nursing area and BIREME, General Documentation Coordination and Information from the Ministry of Health, which is coordinated by EERP/USP, WHO, Collaborating Center.

With regards the impact factors of the journal that shape its importance in the publishing market, there are several meanings of evaluation, such as in the Google Schoolar Citation - the Texto \& Contexto Enfermagem, is one of the three nursing journals with the largest number of citations and, is of of the top six of the 100 most cited Journals in Brazil. With regards the $\mathrm{H}$ index of the SCImago Journal \& Country Rank portal, the Journal expanded its H index from 2 in 2012 to 11 in 2015 and the SJR in 2015 was at 0.371. It is classified as A2 - Qualis CAPES Nursing, dividing this place with four other nursing journals.

The internationalization of the journal is consolidated by the expansion of foreign ad hoc authors and consultants, which has been increasing since the publication in English. However, it is still a challenge to expand this participation.

It is considered that in the conquest of this challenge are intrinsic aspects related to the quality, indexation and Journal Citation Reports (JCR) of the journals, besides the availability of articles in English in open access, as already mentioned, and indexing in databases with international recognition. ${ }^{4}$

From 1992 to 2017 were published 26 volumes, totaling 94 numbers, being 64 regular and 12 special. During this time, 2,299 articles were published, divided into original articles, reflections, experience reports, literature reviews, reviews and previous notes, which undoubtedly had a profound impact on the scientific production of nursing and health in this period .

From March 2012 until February 2017, when we implemented the journal in two languages, a total of 670 articles were published, with more than $80 \%$ of original articles. We understand that scientific journals also have a responsibility to provide readers with original articles that truly contain innovations, clear proposals, theoretical contributions and practical and effective results that can be replicated successfully 
in all parts of the country and internationally. This is one of the great commitments of Journal Texto \& Contexto Enfermagem, when selecting the original articles to be published to each issue, quarterly. ${ }^{3}$

We reiterate that the magazine throughout its 25 years has been, increasingly, as a result of the collective force that engenders and moves, with the deserved quality. The team of the Journal Texto \& Contexto Enfermagem, invests all its effort and potential in this tireless search for the best qualification, with respect to the gratitude to all its authors, readers, ad hoc consultants, who participated and have been participated in this construction, especially to its board of directors, represented by teaching nurses of the PGNP/FUSC, from its inception to the present.

\title{
REFERENCES
}

1. Padilha MI, Costa R, Brüggemann O, Rosa L, Vargas MA, Echevarria Guanilo ME, et al. Texto \& Contexto Enfermagem e sua contribuição para produção científica da enfermagem: uma perspectiva histórica. In: Anais dos XV Encontro Nacional de Editores Científicos, 2015 Nov 22-25 [Internet]. Florianópolis, Brasil. Florianópolis (SC): Associação Brasileira de Editores Científicos; 2015 [cited 2017 Mar 21]. Available from: http:/ / ocs.abecbrasil. org.br/index.php/ENEC/enec/paper/viewFile/84/94

2. Brüggemann OM, Prado ML, Backes VMS, Monticelli M, Padilha MI. Text \& Context Nursing Journal: 15 years of contribution to the socialization of nursing and health knowledge. Texto Contexto Enferm [Internet]. 2007 Out-Dez [cited 2017 Mar 21]; 16(4):769-72. Available from: http:// www.scielo.br/scielo.php?script=sci_arttext\&pid=S010407072007000400023\&lng=p\&tlng=pt

3. Padilha MICS, Ramos FRS. Text \& Context Journal: 20 years of contributing to nursing and health sciences. Texto Contexto Enferm [Internet]. 2012 Mar [cited 2017 Mar 21]; 21(1):11-2. Available from: http:/ / www.scielo.br/scielo. php?script=sci_arttext\&pid=S0104-07072012000100001\&lng=en

4. Padilha MI, Brüggemann O, Costa R, Silva DMGV, Vargas MA, Andrade SR, et al. Internationalization of knowledge and the enhancement of the quality and visibility of scientific Brazilian journals. Texto Contexto Enferm [Internet]. 2014 Jul [cited 2017 Mar 21]; 23(3):517-8. Available from: http:/ / www.scielo.br/scielo.php?pid=S010407072014000300517\&script=sci_arttext

5. Brüggemann OM, Ramos FRS, Padilha MI. Editorial. Texto Contexto Enferm. 2010 Jan-Mar; 19(1):11-2.

\author{
Maria Itayra Padilha \\ Ph.D. in Nursing. Editor-in-Chief of the Text \& Context Nursing Journal
}

Vânia Marli Schubert Backes

Ph.D. in Nursing. Coordinator of the Prograna de Pós-graduação em Enfermagem (PEN) de la Universidad Federal de Santa Catarina (UFSC). Presidente of the Executive council Text \& Context Nursing Journal

\section{Odaléa Maria Brüggemann}

Ph.D. in Obstetrics and Gynecology. Sub-coordinator of the PEN/UFSC.

Vice-presidente of the Executive council Text \& Context Nursing Journal 